\title{
Repair Enzymology
}

National Cancer Institute

\section{Source}

National Cancer Institute. Repair Enzymology. NCI Thesaurus. Code C18998.

The study of the enzymes and mechanisms involved in the repair of damaged DNA. 